\title{
金属パラジウム触媒によるプロピレンのオキシ塩素化反応の機構 ${ }^{122}$
}

\author{
(1973 年 9 月 28 日 受理)
}

\author{
高島 洋明・藤 元 董・功刀 泰 碩*
}

担持パラジウム触媒によるプロピレンのオキシ塩素化反応の機構について研究した。反応原料のらち の一つ（酸素むたは塩化水素）の供給が停止したのちの生成物の生成速度の応答を観察した。酸素の供 給を停止すると塩化アリルの生成速度は約 30 分間にわたってゆるやかに低下した。一方, 塩化イソプ ロピルのそれは変化しなかった。塩化水素の供給を停止すると塩化アリルの生成速度は約 1 時間にわた ってゆるやかに低下した。一方，塩化イソプロピルのそれは数分のらちに0になった。これらの事実か ら, 塩化アリルの生成に寄与する塩素種はパラジウム表面上に強く保持されているが, イソプロピルの それは相対的に弱いといらことが示唆される。

かなり高濃度の $\mathrm{PdCl}_{2}$ がオキシ塩素化反応の定常状態において存在し, その值が 反応条件に依存す ることから, 塩化アリルの生成に寄与する塩素種はパラジウム上に酸化的に吸着されたクロリドアニオ ンであることが示唆される。パラジウムの酸化を促進すると考えられるいくつかの触媒（活性炭, 塩化

銅，硝酸）は塩化アリルの生成に対し加速効果を示す。

本反応の機構を速度論的手法により解析した。

\section{1 緒言}

著者らはさきに担持金属パラジウムその他の白金族金属触媒を 用いるとプロピレンのオキシ塩素化反応が進行することを見いだ しだ)。そしてその反応についていろいろ検討した結果, 塩化ア リルは金属パラジゥム上に生成した $\pi$-アリル中間体の末端の炭 素を，触媒上に強く吸着した塩素が求核的に攻整することによっ て生成するといら反応径路を示唆した。しかし前報に打いて展開 した反応速度を中心とする議論は定常状態に拈ける反応器の入口 と出口の情報のみから組み立てられたるのであり，作用状態にお ける触媒表面上の活性点, 吸着種など, 触媒反応の本質にかかわ る情報が含まれていなかった。

そこで本報に拈いては，（i ）流通式反応装監を用いて，定常 に達したオキシ塩素化反応の系から反応原料, たとえば, 酸素や 塩化水素を突然カットする非定常操作に対する反応結果の時間変 化によって触媒の動的特性を調べることにより，吸着種および活 性点を推察した。（ii）オキシ塩素化反応に扣いて金属パラジウ ム上に化学吸着した塩素を, いろいろの方法で定量することによ り, 作用状態に和けるパラジウムの荷電状態を推定し,オキシ塩 素化反応に持けるパラジゥムの酸化還元過程の役割を考察した。 （iii）パラジウムの再酸化の過程を加速すると思われる助触媒， たとえば活性炭(担体を兼ねる), 塩化銅 (II), 硝酸などを反応系 に付加した場合の全反応速度の変化を調べ，全反応の中でパラジ

1）この報文を“貫金属触媒による炭化水素の選択的酸化反応 (第 5 報)”とする.

2）前報(第 4 報)；藤元 蒸, 高島 洋明, 功刀泰碩, 日 化, $1974,428$.

* 東京大学工学部合成化学科, 113 東京都文京区本郷

3）高島洋明, 藤元 恭, 功刀泰碩, 日化, 1972, 2297. ウムの再酸化過程が占める位監を考察した。（iv）以上の諸点を 踏まえた上で，あらためて反応機構を考察した結果を報告する。

\section{2 実験}

实験装置は通常の固定床流通式反応装置を使用した。プロピレ ン, 酸素, 窒素扣よび塩化水素はオリフィス流量計で計量後, 塩 化カルシウム充テン管を通して乾燥したのち反応器に導入した。 水または塩化水素水は湤状で反応器に供給し, 反応器上部で気化 させたのち他の反応ガスと混合し，触媒層を通過させた。液状生 成物は寒剂（塩化ナトリウムー氷）で冷却した塩化ェチレンに吸収 させ, ガス状生成物はせッケン膜流量計で計量後排気した。非定 常反応操作の場合は液状生成物もガス状で分析した。原料の純度, 触媒調製法などについては既報》を参照されたい。生成物の分析 は有機物は PEG 1500 を固定相とするガスクロマトグラフで分析 した。二酸化炭素はポラパックQをカラムとするガスクロマトグ ラフで分析した。

\section{3 実 験 結 果}

\section{1 塩化水素の供給停止に対する触媒の応答}

図 1 亿定常状態に達したプロピレンのオキシ塩素化反応に拁い て塩化水素の供給を突然停止し，ふたたび開始したときの生成物 の応答を示した。この操作の間, 酸素の分圧とプロピレンの分王 には変動が起こらないように窒素で調節した。図1から明らかな ように塩化水䋕の供給を停止すると塩化イソプロピルの生成速度 は供給停止後数分間で急激に低下し 10 分後には 0 になってしま らのに対し, 塩化アリルの生成速度は, 気相中にはもはや完全に 塩化水素が存在しないと思われる 10 分後にも定常值の $1 / 3$ 程度 までしか低下せず，1時間近くでほとんど0になるまでゆるやか 


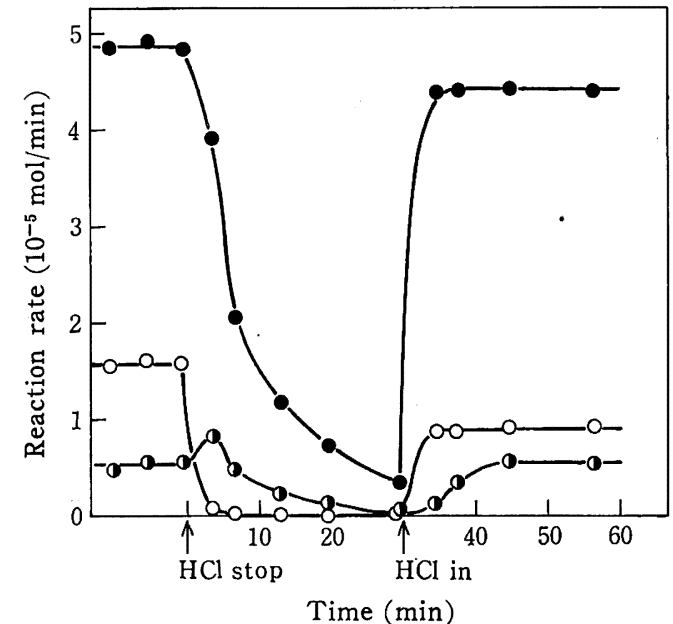

Fig. 1 Response to $\mathrm{HCl}$ feed stop

: Allyl chloride, $\bigcirc:$ Isopropyl chloride,

(1) : 2-Dichloropropane

$1 \mathrm{wt} \% \mathrm{Pd} / \mathrm{A}$. C., Temp. : $235^{\circ} \mathrm{C}, W / F=5.8 \mathrm{~g}$-cat $\cdot \mathrm{hr} / \mathrm{mol}$

に低下する。供給停止後 30 分後に供給を開始すると塩化アリル の生成速度も塩化イソプロピルの生成速度も数分の間に定常值に 達する。1,2-ジクロロプロパンの挙動は塩化アリルのそれに類似 している。

\section{2 酸素の供給停止に対する触媒の応答}

図 2 に反応系への酸素の供給停止执よび再開に対する触媒の応 答を示した。酸素の供給を停止すると塩化アリルの生成速度は急 激に低下し，10 分後には定常值の約 10 分の 1 になってしまう。 それに対し酸素の供給停止後も塩化イソプロピルの生成速度はほ とんど変化しない。供給停止 30 分後に供給を開始すると塩化ア リルの生成速度は数分のちにもとの定常值に回復する。一方, 塩 化イソプロピルの生成速度には变化はみられない。1,2-ジクロロ プロパンの挙動はこの場合も,塩化アリルのそれに類似している。 3.3 Wacker 型反応の応用による 2 価のパラジウム量の測定 活性炭に担持した塩化パラジウムが Wacker 反応のよい触媒 となることが藤元らによって報告されている4)。反応速度論的解

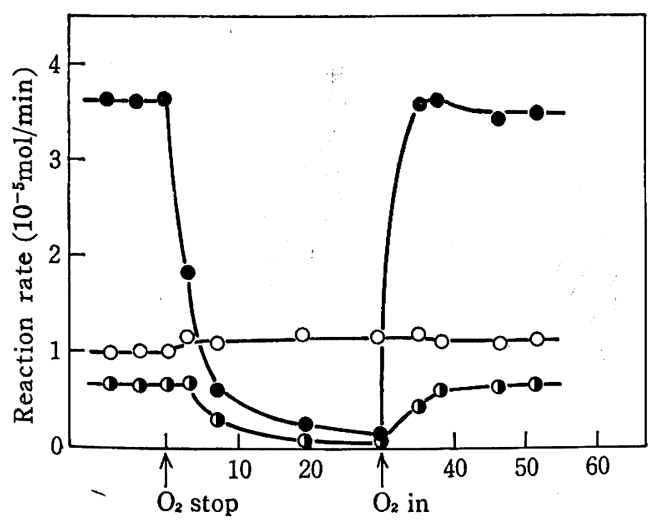

Time ( $\mathrm{min}$ )

Fig. 2 Response to $\mathrm{O}_{2}$ stop

: Allyl chloride, $\bigcirc$ : Isopropyl chloride, : : 1,2-Dichloropropane

$1 \mathrm{wt} \% \mathrm{Pd} / \mathrm{A}$. C., Temp. : $235^{\circ} \mathrm{C}, W / F=5.8 \mathrm{~g}$-cat $\cdot \mathrm{hr} / \mathrm{mol}$
析の結果, パラジウムが 2 価と 0 価の間を往復する過程で触媒作 用を示すと結諭されている。そして，アセトンの生成速度は作用 状態に拈ける 2 価のパラジウムの量に直接的に対応している。著 者らはこの関係を用いれば, オキシ塩素化反応の作用状態に扣け る金属パラジウムー活性炭触媒表面上の 2 価のパラジウム量を推 定し得ると仮定して，オキシ塩素化反応に执いて定常状態に達し た触媒を窒素で完全にパージしたのちプロピレンの Wacker 反 応を行ない,アセトンの生成速度を測定した。

実験の操作はつぎのように行なった。プロピレンのオキシ塩素 化反応を開始し, 反応が定常に達したところで窒素で反応系を十 分に直換し，つぎにその触媒を用いてプロピレンの Wacker 反 応を温度 $100^{\circ} \mathrm{C}$, プロピレン: 酸素 : 水 $=4: 1: 6$ (モル比), W/F $=8.0(\mathrm{~g}-\mathrm{cat} \cdot \mathrm{hr} / \mathrm{mol})$ の条件で行なう。

表 1 に 4 種類のパラジウム触媒を用いたときのプロピレンの Wacker 反応に拈けるアセトンの生成速度を示した。表から塩化

Table 1 Estimation of the amount of $\operatorname{Pd}($ II $)$ by the Wacker reaction

\begin{tabular}{|c|c|c|}
\hline Catalyst & $\begin{array}{c}\text { Rate of acetone } \\
\text { formation } \\
\left(10^{-4} \mathrm{~mol} / \mathrm{g}-\right. \\
\text { cat } \cdot \mathrm{hr})\end{array}$ & $\begin{array}{l}\text { Rate of allyl } \\
\text { chloride for- } \\
\text { mation }\left(10^{-4}\right. \\
\text { mol } / g-\text { cat } \cdot h r)\end{array}$ \\
\hline $\mathrm{PdCl}_{2} /$ A.C. (fresh) & 9.3 & - \\
\hline $\begin{array}{l}\mathrm{PdCl}_{2} / \text { A.C. (used for } \\
\text { oxychlorination) }\end{array}$ & 4.5 & 1.4 \\
\hline $\begin{array}{l}\text { Pd/A.C. (used for } \\
\text { oxychlorination) }\end{array}$ & 4.3 & 1.2 \\
\hline Pd/A.C. (fresh) & trace & - \\
\hline
\end{tabular}

Pd/A.C. (fresh)

trace

Catalyst : $1 \mathrm{wt} \%$, Temp. : $100^{\circ} \mathrm{C}, W / F=8.0 \mathrm{~g}-\mathrm{cat} \cdot \mathrm{hr} / \mathrm{mol}$, $\mathrm{C}_{3} \mathrm{H}_{6}: \mathrm{O}_{2}: \mathrm{H}_{2} \mathrm{O}=4: 1: 6$ (mole ratio)

a) Temp. : $200^{\circ} \mathrm{C}, W / F=8.2 \mathrm{~g}$-cat $\cdot \mathrm{hr} / \mathrm{mol}, \mathrm{C}_{3} \mathrm{H}_{6}: \mathrm{O}_{2}$ : $\mathrm{HCl}: \mathrm{H}_{2} \mathrm{O}=4: 2: 1: 10$

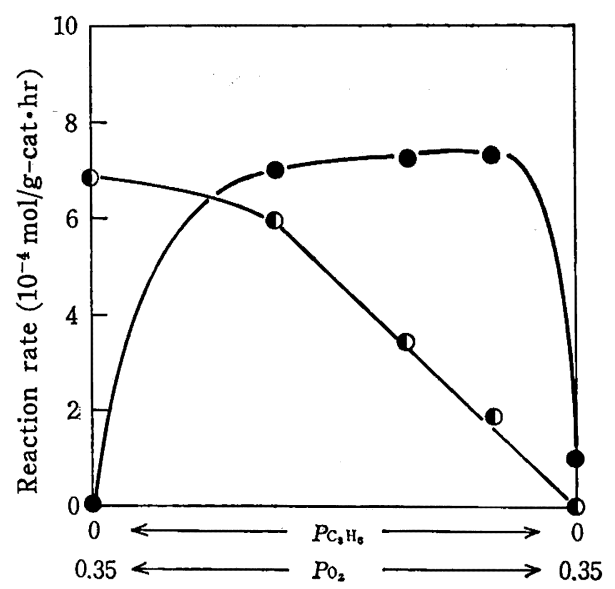

Partial pressure in oxychlorination (atm)

Fig. 3 Oxidation state of palladium in oxychlorination reaction

: Allyl chloride, 0 : Acetone

Oxychlorination -

1 wt $\%$ Pd/A.C., Temp. : $240^{\circ} \mathrm{C}, W / F=5.8 \mathrm{~g}$-cat $\cdot \mathrm{hr} /$ $\mathrm{mol}$

Wacker reaction

$\mathrm{Pd}$ catalyst used in oxychlorination, Temp.: $100^{\circ} \mathrm{C}$, $W / F=8.0 \mathrm{~g}$-cat $\cdot \mathrm{hr} / \mathrm{mol}$

4）藤元 萲, 根上泰碩, 工化, 73, 1822(1970). 
Table 2 Rate of allyl chloride formation

\begin{tabular}{|c|c|c|}
\hline Catalyst & $\begin{array}{c}\text { Surface area } \\
\left(\mathrm{m}^{2} / \mathrm{g}\right)\end{array}$ & $\begin{array}{l}\text { Rate of formation } \\
\left(10^{-4} \mathrm{~mol} / \mathrm{g} \text {-cat } \cdot \mathrm{hr}\right)\end{array}$ \\
\hline Pd/A. C. & 1310 & 4.2 \\
\hline $\mathrm{Pd} /$ Silica $\left.\mathrm{gel}^{a}\right)$ & 420 & 0.73 \\
\hline $\mathrm{Pd} /$ Alumina ${ }^{b)}$ & 150 & 0.66 \\
\hline
\end{tabular}

Catalyst : $1 \mathrm{wt} \%$, Temp. : $230^{\circ} \mathrm{C}, W / F=12 \mathrm{~g}$-cat $\cdot \mathrm{hr} / \mathrm{mol}$, $\mathrm{C}_{3} \mathrm{H}_{6}: \mathrm{O}_{2}: \mathrm{HCl}: \mathrm{H}_{2} \mathrm{O}=4: 2: 1: 10$ (mole ratio)
a) Tokai Gel.
b) Neobead C.

Table 3 Effect of addition of $\mathrm{CuCl}_{2}$

\begin{tabular}{lccc}
\multicolumn{1}{c}{ Catalyst } & \multicolumn{3}{c}{$\begin{array}{c}\text { Rate of formation } \\
\left(10^{-4} \text { mol/g-cat.hr }\right)\end{array}$} \\
\cline { 2 - 4 } $\begin{array}{c}\text { Allyl } \\
\text { chloride }\end{array}$ & $\begin{array}{l}\text { Isoprpyl } \\
\text { chloride }\end{array}$ & $\mathrm{CO}_{2}$ \\
\hline Pd/Alumina & 0.66 & 0.36 & 0.18 \\
$\left(\mathrm{Pd}+\mathrm{CuCl}_{2}\right) /$ Alumina & 1.3 & 0.52 & 0.25
\end{tabular}

Catalyst : $1 \mathrm{wt} \%$, Temp. : $230^{\circ} \mathrm{C}, \mathrm{Pd}: \mathrm{Cu}=1: 1$ (atom ratio), $\mathrm{C}_{3} \mathrm{H}_{6}: \mathrm{O}_{2}: \mathrm{HCl}: \mathrm{H}_{2} \mathrm{O}=4: 2: 1: 10$ (mole ratio)

Table 4 Effect of addition of nitric acid

\begin{tabular}{|c|c|c|c|}
\hline \multirow{2}{*}{ Reactants } & \multicolumn{3}{|c|}{$\begin{array}{l}\text { Rate of formation } \\
\left(10^{-4} \mathrm{~mol} / \mathrm{g} \text {-cat } \cdot \mathrm{hr}\right)\end{array}$} \\
\hline & $\begin{array}{c}\text { Allyl } \\
\text { chloride }\end{array}$ & $\begin{array}{l}\text { Isopropyl } \\
\text { chloride }\end{array}$ & $\mathrm{CO}_{2}$ \\
\hline $\begin{array}{c}\mathrm{C}_{3} \mathrm{H}_{6}+\mathrm{O}_{2}+\mathrm{HCl}+\mathrm{H}_{2} \mathrm{O} \\
4: 2: 1: 8^{*}\end{array}$ & 3.7 & 2.2 & 1.8 \\
\hline $\begin{array}{c}\mathrm{C}_{3} \mathrm{H}_{6}+\mathrm{O}_{2}+\mathrm{HCl}+\mathrm{H}_{2} \mathrm{O}+\mathrm{HNO}_{3} \\
4: 2:=1: 6: 2^{*}\end{array}$ & 5.1 & 2.4 & 2.7 \\
\hline \multicolumn{4}{|c|}{$\begin{array}{l}\text { Catalyst : } 1 \mathrm{wt} \% / \mathrm{A} . \mathrm{C} ., \quad W / F=14 \mathrm{~g} \text {-cat } \cdot \mathrm{hr} / \mathrm{mol} \text {, } \\
\text { Temp. : } 200^{\circ} \mathrm{C}\end{array}$} \\
\hline
\end{tabular}

パラジウムー活性炭触媒であれ，金属パラジウムー活性炭触媒であ れ，オキシ塩素化反応に扮いて定常活性を示した触媒のアセトン 生成速度はいずれる同程度となり，その值は未使用の塩化パラジ ウム触媒によるアセトン生成速度の約 2 分の 1 になることがわか る。オキシ塩素化反応を経験しない金属パラジウム触媒にアセト ン生成活性が見られないことは従来の結果と一致する。

つぎ同様に Wacker 反応を応用して，いろいろの酸化，還 元雾囲気でオキシ塩素化反応を行なった場合における触媒表面上 の 2 価のパラジウム量を測定した結果を図 3 に示した。図 3 で特 徵的なことは塩化アリルの生成速度そのbのは酸化還元雾囲気の 変動に鈍感であるのに対し，アセトンの生成速度は敏感で酸化雲 囲気になるほどその値が増大している。

\section{4 ハラジウムの再酸化過程を加速する助触媒の影響}

3.4.1 活性炭担体の加速作用: 表 2 亿触媒担体として活性炭, シリカゲル，アルミナを用いた場合の反応結果を比校した。

3.4.2 塩化銅の添加効果: 表 3 にアルミナ担体(水沢化学ネオ ビード）に塩化銅を助触媒として担持させた場合の効果を示し た。

3.4.3 硝酸の添加効果: 表 4 飞硝酸を他の反応原料とともに 反応系に供給したときの反応結果を示した。

\section{4 考察}

\section{1 作用状態におけるパラジウムの酸化状態}

図 1 で塩化水素の供給停止数分後で塩化イソプロピルの生成が
停止してしまったことは，気相中に完全に塩化水素がなくなった

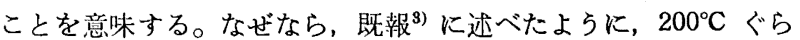
いの温度で塩化イソプロピルの一部は気相反応からる生成するか らである。したがって，少なくとも塩化イソプロピルの生成が停 止したのち約 1 時間にわたって生成してきた塩化アリルの塩素源 は，作用状態に和いて触媒表面上に吸着されていた塩素に求めら れなければならない。塩化イソプロピルの生成停止後に生成した 塩化アリルのモル数を皘分してみると，担持された金属パラジウ ムのモル数（約 $0.2 \mathrm{mmol}$ ) とほぼ等しい值を得る。また表 1 の 結果から，オキシ塩素化反応の定常状態においては，担持した金 属パラジウムの約 2 分の 1 が塩化パラジウムになっていることが 示唆される。この数量関係の合理的解釈としてつぎのことが考兄 られる。

塩化水素の供給を停止したのち塩化アリルは

$$
\begin{aligned}
& \mathrm{PdCl}_{2}+\underset{\mathrm{CH}_{2}}{\stackrel{\mathrm{C}}{\mathrm{C}} \underset{\mathrm{Pd}}{\mathrm{C}}-\mathrm{H}} \longrightarrow \text { Allyl chloride }+\mathrm{H}-\mathrm{Pd}-\mathrm{Cl}+\mathrm{Pd} \\
& 2 \mathrm{H}-\mathrm{Pd}-\mathrm{Cl}+1 / 2 \mathrm{O}_{2} \longrightarrow \mathrm{PdCl}_{2}+\mathrm{H}_{2} \mathrm{O}+\mathrm{Pd}
\end{aligned}
$$

なる反応により生成すると考える。塩素の吸着種として $\mathrm{PdCl}_{2}$ を ・考えたのは, 表 1 でオキシ塩素化反応使用後の触媒にアセトン生 成活性があることに基つく。（1）の右辺の $\mathrm{H}-\mathrm{Pd}-\mathrm{Cl}$ は（2）式 によって $\mathrm{PdCl}_{2}$ にもどるか，または， $\mathrm{H}-\mathrm{Pd}-\mathrm{Cl} \longrightarrow \mathrm{Pd}+\mathrm{HCl}$ といら反応によって $\mathrm{HCl}$ を気相中に放出するかの 2 通りの場合 が考えられるが，後者は，プロピレンへの塩化水素付加生成物で ある塩化イソプロピルの生成が，塩化水素の供給停止後急に停止 するという実験事実に矛盾することにより否定され， $\mathrm{H}-\mathrm{Pd}-\mathrm{Cl}$ は (2) 式によって $\mathrm{PdCl}_{2}$ にもどると考えられる。結局，（1）式, (2) 式により量論的には $\mathrm{PdCl}_{2}$ の量の 2 倍の（したがって担持 された金属パラジウムのモル数とほぼ等しい）塩化アリルが生成 することになり，上記の数量関係が満足されている。

上記議論に打いて推定した塩素の吸着形態は以下に述べる事実 から支持される。すなわち，（i）表1K見られるように，塩化 パラジウムー活性炭触媒にも金属パラジウムー活性炭触媒と同様, 塩化アリル初期活性が見られること。これは金属パラジウム触媒 によるプロピレンの酸化的置換反応のうち，たとえばオキシアセ トキシル化反応 ${ }^{5)}$ あるいはオキシ水和反応6) ある。（ii）塩化パラジウムとプロピレンからの $\pi$-アリル錯体が, Hüttel らによって単離されて拈り，その熱的レドックス分解に よって塩化アリルと0 価パラジウムが生成することが知られてい ること7)。プロピレンは低温では塩化パラジウム上に $\pi$-配位する が，高温になるにつれて て和り，著者らの行なった実験条件 $\left(200^{\circ} \mathrm{C}\right.$ 以上) では, 塩化パ

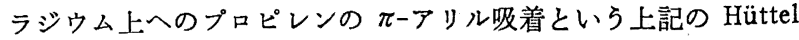
らの機構も十分飞考えられる。（iii）塩化パラジウムは生成䏶 $\left(\Delta H_{\mathrm{f}}{ }^{0}\right)$ が $-45.4 \mathrm{kcal} / \mathrm{mol}$ とかなり安定であるので

$$
\mathrm{Pd}+2 \mathrm{HCl}+1 / 2 \mathrm{O}_{2} \longrightarrow \mathrm{PdCl}_{2}+\mathrm{H}_{2} \mathrm{O}
$$

なる量論式によって容易に生成し得ると考えられること。

5）荒井弘通，小島慎二，藤元 渪，功刀泰碩，工化， 72 , 1767 (1969).

6) 藤元 蕙, 吉野浩樹, 功刀泰碩, 日化, 1972, 507.

7) R. Hüttel, J. Kratzer, Angew. Chem., 71, 465(1959) 
図 2 の結果は酸素に対する塩化イソプロピルと塩化アリルのき わめて対照的な挙動を示す。量諭式から考えても前者はプロピレ ンと塩化水素の単なる付加生成物であるのに後者は必然的に酸化 的な脱水素過程を含むるのであり，酸素に対する挙動の差は十分

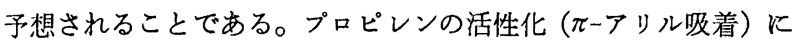
は酸素を必要としないとされているから, 酸素は上記のように求 核試薬である塩化水素の活性化（すなわち酸化吸着）に必要と考 えられる。また図 2 に沶いてす図 1 と同様に塩化アリルの減少が ゆるやかであることも触媒それ自体が酸化力を有する状態で塩化 物イオンを吸着していることを意味する。このことは表 1 の結果 ああわせて考えるとより明暸となる。表 1 でオキシ塩素化使用後 の塩化パラジウムー活性炭触媒も金属パラジウムー活性炭触媒もプ ロピレンの Wacker 反応に执いてほほ等しいアセトン生成活性 を示すことから，反応が定常に達したときにはパラジウムはその 酸化還元雾囲気に応じた酸化状態をとっていると結論される。し たがって，より酸化的雾囲気でオキシ塩素化反応を行ならほど, 作用状態に拈ける触媒表面の酸化の程度は高い。すなわち, 酸化 的に塩素化されたパラジゥムの濃度が高くなり，アセトン生成活 性が高いことが予測され，それは図 3 から明らかである。以上の 結果は金属パラジウム触媒によるプロピレンのオキシ塩素化反応 に拈いて, パラジウムの酸化還元が実際に起こっていることを示 している。

表 2〜4 をでの結果は活性炭, 塩化銅, 硝酸などを助触媒的に 用いると，主反応である塩化アリルの生成が加速されることを示 している。活性炭4)，塩化銅はいずれる Wacker 型反応に执いて 0 価のパラジゥムを 2 洒に再酸化するための助触媒として有名な ものであり，硝酸もパラジウムの酸化触媒になることが知られて いる8)。表 2〜4 の結果はしたがってパラジウムの酸化促進が少 なくとも全反応の不可欠の一部となっている上記機構を支持す る。

\section{2 反応の速度論的検討}

以上の結果を湍足する反応機構を考察するにあたって，二つの 対照的な反応モデル，すなわち（i）完全レドックス機構和よび (ii) 部分レドックス機構について考察する。（i ）は Wacker 型 反応の反応機構として広く認められているものであり，(ii)はプ ロピレンのオキシ水和反応()，オキシアセトキシル化反応 ${ }^{5)}$ につ いて提出されている反応機構である。

4.2.1 完全レドックス機構：パラジウムが 0 価と 2 価の間を 往復するといら完全レドックス機棈は

$$
\mathrm{PdCl}_{2}+\mathrm{CH}_{2}=\mathrm{CH}-\mathrm{CH}_{3} \stackrel{k_{1}}{\longrightarrow} \mathrm{CH}_{2}=\mathrm{CH}-\mathrm{CH}_{2}-\mathrm{Cl}+\mathrm{Pd}_{0}+\mathrm{HCl}
$$

$$
\mathrm{Pd}_{0}+2 \mathrm{HCl}+1 / 2 \mathrm{O}_{2} \stackrel{k_{2}}{\longrightarrow} \mathrm{PdCl}_{2}+\mathrm{H}_{2} \mathrm{O}
$$

の雨式であらわされ，定常状態の仮定を置くと

$$
\frac{\left[\mathrm{Pd}^{2+}\right]}{\left[\mathrm{Pd}^{0}\right]+\left[\mathrm{Pd}^{2+}\right]}=\frac{k_{2} f_{2}\left(P_{\mathrm{HCl}}, P_{\mathrm{O}_{2}}\right)}{k_{1} f_{1}\left(P_{\mathrm{C}_{3} \mathrm{H}_{6}}\right)+k_{2} f_{2}\left(P_{\mathrm{HCl}}, P_{\mathrm{O}_{2}}\right)}
$$

(塩化アリル生成速度) $\equiv v$

$$
=\frac{k_{1} k_{2} f_{1}\left(P_{\mathrm{C}_{3} \mathrm{H}_{6}}\right) f_{2}\left(P_{\mathrm{HCl}}, P_{\mathrm{O}_{2}}\right)}{k_{1} f_{1}\left(P_{\mathrm{C}_{3} \mathrm{H}_{6}}\right)+k_{2} f_{2}\left(P_{\mathrm{HCl}}, P_{\mathrm{O}_{2}}\right)}\left(\left[\mathrm{Pd}^{0}\right]+\left[\mathrm{Pd}^{2+}\right]\right)
$$

ただし， $f_{1}\left(P_{\mathrm{C}_{3} \mathrm{H}_{6}}\right) ， f_{2}\left(P_{\mathrm{HCl}}, P_{\mathrm{O}_{2}}\right)$ はそれぞれ，プロピレン分压

8）田村益彦，安井昭夫，工化，72，575(1969).
の関数, 塩化水素分圧と酸素分圧の関数をあらわす。

いま, $f_{1}\left(P_{\mathrm{C}_{3} \mathrm{H}_{6}}\right)=P_{\mathrm{C}_{3} \mathrm{H}_{6}}, f_{2}\left(\mathrm{HCl}, \mathrm{O}_{2}\right)=k P_{\mathrm{O}_{2}}$ (たたし， $P_{\mathrm{HCl}}$ 一 定の場合）と仮定し， $k k_{2} \equiv k_{2}^{\prime}$ とすると

$$
\begin{aligned}
& \frac{\left[\mathrm{Pd}^{2+}\right]}{\left[\mathrm{Pd}^{0}\right]+\left[\mathrm{Pd}^{2+}\right]}=\frac{k k_{2} P_{\mathrm{O}_{2}}}{k_{1} P_{\mathrm{C}_{3} \mathrm{H}_{6}} k k_{2} P_{\mathrm{O}_{2}}}=\frac{k_{2}{ }^{\prime} P_{\mathrm{O}_{2}}}{k_{1} P_{\mathrm{C}_{3} \mathrm{H}_{6}}+k_{2}{ }^{\prime} P_{\mathrm{O}_{2}}} \\
& v=\frac{k_{1} k_{2}^{\prime} P_{\mathrm{C}_{3} \mathrm{H}_{6} P_{\mathrm{O}_{2}}}}{k_{1} P_{\mathrm{C}_{3} \mathrm{H}_{6}}+k_{2} P_{\mathrm{O}_{2}}}
\end{aligned}
$$

(5) 式を $P_{\mathrm{C}_{3} \mathrm{H}_{6}}$ に対してプロットすると図4のようになる。 (5)式の左辺は定常状態に和ける触媒表面上の 2 価のパラジウム の濃度に対応するるのであるから,その值はプロピレンのWacker 型反応を考劣る場合はアセトンの生成速度に比例するはずであ る。図3のアセトン生成速度に比例するはずである。四３のアセ トン生成速度と酸素分圧の関係を示すグラフは四 4 のものと同一 の傾向を示している。一方，(6)式の右辺はプロピレンのオキシ 塩素化反応の全反応速度であり, その值と $P_{\mathrm{O}_{2}}$ の值の関係は図 5 に示すグラフとなる。これを図 3 のグラフと比較するとあまり よい一致は見られない。つまり完全レドックス機構はオキシ塩素 化反応を十分に説明するとは断じ難い。

4.2.2 部分レドックス機構: 部分レドックス機構は, プロピ レンの活性化が金属パラジウムにより，塩素は $\mathrm{PdCl}_{2}$ を通して反 応に関与するとする考学であるが，それに完全レドックス機構と 同様の動的扱い方をすることはいちじるしく複雑なので Langmuir-Hinshelwood 型の整理を行なった。

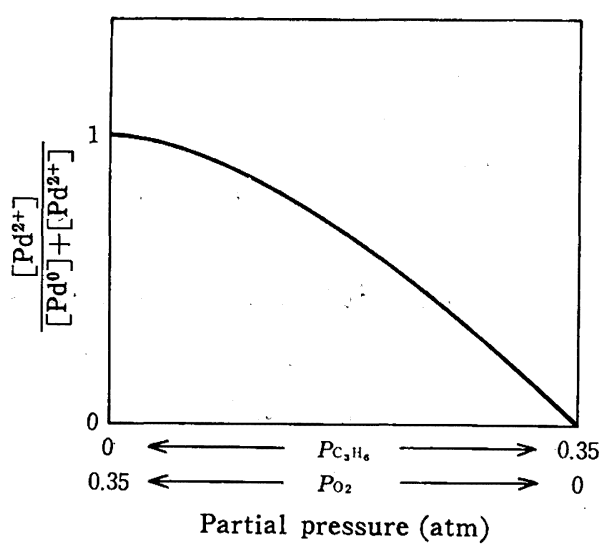

Fig. 4 Estimation of $\mathrm{Pd}^{2+}$ by complete redox model

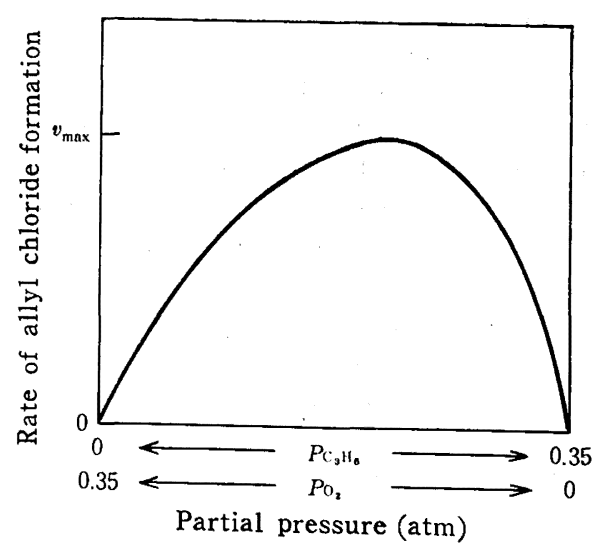

Fig. 5 Estimation of rate of allyl chloride formation by complete redox model 


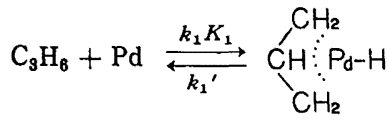

$\mathrm{O}_{2}+2 \mathrm{Pd} \underset{k_{2}^{\prime}}{\stackrel{k_{2} K_{2}}{\rightleftarrows}} 2 \mathrm{Pd}-\mathrm{O}$

$\mathrm{Pd}-\mathrm{O}+2 \mathrm{HCl} \underset{k_{3}{ }^{\prime}}{\stackrel{k_{3} K_{3}}{\rightleftarrows}} \mathrm{PdCl}_{2}+\mathrm{H}_{2} \mathrm{O}$

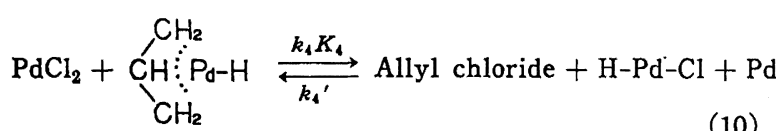

$2 \mathrm{H}-\mathrm{Pd}-\mathrm{Cl}+\mathrm{Pd}-\mathrm{O} \underset{k_{5^{\prime}}}{\stackrel{k_{5} K_{5}}{\rightleftarrows}} \mathrm{PdCl}_{2}+\mathrm{H}_{2} \mathrm{O}+\mathrm{Pd}$

（10)式を律速段階とし， H-Pd-Cl の濃度が小であるとすれば

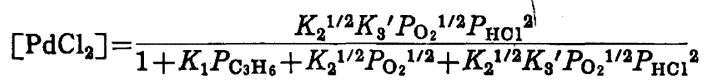

(塩化アリル生成速度) 三v

$$
\begin{aligned}
& =\frac{K_{1} K_{2}{ }^{1 / 2} K_{8}{ }^{\prime} P_{\mathrm{C}_{3} \mathrm{H}_{6}} P_{\mathrm{O}_{2}}{ }^{1 / 2} P_{\mathrm{HCl}^{2}}{ }^{2}}{\left(1+K_{1} P_{\mathrm{C}_{3} \mathrm{H}_{6}}+K_{2}{ }^{1 / 2} P_{\mathrm{O}_{2}}{ }^{1 / 2}+K_{2}{ }^{1 / 2} K_{3} P_{\mathrm{O}_{2}}{ }^{1 / 2} P_{\mathrm{HCl}^{2}}\right)^{2}} \\
& \left(\text { ただし, } K_{3}{ }^{\prime} \equiv \frac{K_{3}}{P_{\mathrm{H}_{2} \mathrm{O}}}\right)
\end{aligned}
$$

（13）式は既報 ${ }^{3)}$ の塩化アリル生成速度の分圧依存性をほぼ説明 し得る。そしてこの速度式の特徵はオキシ水和反応の)あるいはオ キシアセトキシル化反応》) のそれに比較して, 㯰換荗である $\mathrm{HCl}$ の吸着がいちじるしく大であること，また $\mathrm{PdCl}_{2}$ なる明確に塩 の形をとる中間体を想定していることである。(13) 式に特ける $K_{\mathbf{3}}{ }^{\prime}$ の值が $K_{1}$ および $K_{2}$ に比較していちじるしく大であること により，見かけの分圧依存性はその他の反応といちじるしく異な る。また（12）式す $K_{3}{ }^{\prime}$ が $K_{1}$ 扰よび $K_{2}$ に比較して大であれ
ば, 少量の塩化水素で $\mathrm{PdCl}_{2}$ 涉度は一定値をとることがわかる。 また図 3 の $\mathrm{PdCl}_{2}$ 浱度の $P_{\mathrm{C}_{3} \mathrm{H}_{6}}, P_{\mathrm{O}_{2}}$ 依存性とも定性的に一致す る。さらに表 2 4 4 に示した酸化促進剂の反応促進效果は $K_{3}$ を 大きくすることにより $\mathrm{PdCl}_{\mathbf{2}}$ 濃度を大にしていると考えてよい であろら。

以上，二つの反応モデルについて比较検討したが，どちらか一 方のみでは㬰験結果とのズレを避け得ない。真の反応機構は二つ の対照的なモデルの中間的なるのであろら。別の表現をすれば， オキシ塩素化反応がオキシ水和反応(6)，オキシアセトキシル化反 応占のよらに, 部分レドックス機構のみでは説明がつかないとこ ろに酸化的アリル位置換反応の求核試薬としての水蒸気(水酸基) あるいは酢酸（アセトキシル基）と塩化水素（クロル基）との質 的な差があらわれていると見られる。まず第一にいえることはパ ラジウムとの親和力の差である。塩素とパラジウムの親和力はき わめて強く(結合エネルギーが大きく), 作用状態に打いてパラジ ウムのまわりには多量の塩素が強く吸着しており, その活性化に は，水蒸気または酢酸などにくらへ高い温度が必要となる。第二 に塩化パラジウムが安定であることから必然的に反応条件下に拉 いても塩化パラジウムまで酸化これてしまうことを考虑しなけれ ばならない。これは水蒸気あるいは酢酸の場合には考える必要が ない。したがって Langmuir-Hinshelwood 型の速度式の遒出の

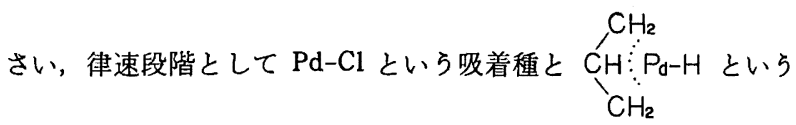
吸着種の表面反応を考えずに $\mathrm{PdCl}_{2}$ と等 考えた。ただし， Pd-Cl のよらな吸着種の奇与がまったくないと はいい切れない。

\title{
The Mechanism of Palladium-catalyzed Oxychlorination of Propylene
}

\author{
Hiroaki Takashima, Kaoru Fujimoto and Taiseki Kunugi \\ Department of Synthetic Chemistry, Faculty of Engineering, University of Tokyo ; \\ Hongo, Bunkyo-ku, Tokyo 113 Japan
}

The mechanism of oxychlorination of propylene over supported metallic palladium catalyst was studied. The change in the products formation with time was observed after the supply of one of the reactants (oxygen or hydrogenchloride) was stopped. If the feed of oxygen was stopped, the rate of allyl chloride formation fell slowly to zero in about 30 minutes, whereas that of isopropyl chloride did not change. On the other hand, if the feed of hydrogenchloride was stopped the rate of allyl chloride formation fell slowly to zero in about an hour, whereas that of isopropyl chloride fell to zero in a few minutes. These observations suggested that the chloride species participating in allyl chloride formation were held strongly on palladium surface, but those related to isopropyl chloride were comparatively held weakly. The fact that considerable amount of palladium chloride was formed in the catalyst during oxychlorination and the amount of it depended on the reaction condition suggested the chloride species concerning allyl chloride formation being chloride anion which has been oxidatively adsorbed on the palladium.

Some cocatalysts (active carbon, cupric chloride and nitric acid) which had been considered to promote the oxidation of palladium, accelerated the rate of allyl chloride formation.

The mechanism was analyzed by the kinetic method.

$\dagger$ Selective Oxidation of Olefines over Noble Metal Catalysts. V. 